\title{
Role of Tissue Factor in Atherothrombosis
}

\author{
A. Phillip Owens III ${ }^{\star}$ and Nigel Mackman \\ Department of Medicine, Division of Hematology and Oncology, McAllister Heart Institute, \\ University of North Carolina at Chapel Hill, 98 Manning Drive Campus Box 7035, Chapel Hill, NC \\ 27599, USA
}

\section{Abstract}

Atherothrombosis describes the acute thrombotic event that occurs after rupture of an atherosclerotic plaque. It often leads to arterial occlusion and subsequent clinical manifestations of myocardial infarction, stroke, and sudden death. Tissue factor (TF) is the receptor for plasma factor VIIa (FVIIa) and, once formed, the TF:FVIIa complex activates the coagulation cascade. TF is present at high levels within atherosclerotic lesions and is also present on circulating monocytes and microparticles in patients with advanced cardiovascular disease (CVD). Formation of the TF:FVIIa complex plays a central role in atherothrombosis. This review will describe the cellular sources of TF, the potential of TF-positive microparticles as a biomarker of thrombotic risk, and current pharmacologic approaches to inhibit $\mathrm{TF}$ as a therapeutic intervention in patients with CVD.

\section{Introduction}

Atherothrombosis is the result of atherosclerotic plaque disruption and subsequent arterial thrombosis, which culminates in arterial occlusion and myocardial infarction or stroke. Atherosclerosis and subsequent atherothrombosis is one of the most devastating disease states in the Western world accounting for more than $25 \%$ of deaths in the United States in any given year, which is the leading cause of death in both men and women [1-3]. In addition, the projected cost of coronary heart disease in the United States was over $\$ 100$ billion in 2010 due to health care services, medications, and lost worker production [4]. Characterized as a disease of cholesterol deposits in macrophages and the vessel wall in small and medium sized arteries, it is more comparable to an autoimmune insult on the main transport vesicle for cholesterol, low density lipoprotein (LDL), after progressive oxidation. Atherosclerosis is undetectable without specific radiographic examinations or invasive procedures. Recently, atherosclerosis has been redefined as an inflammatory disease due to the combined cellular and molecular analyses of atherosclerotic lesions (reviewed in detail [5]). Recently, much clinical interest has been generated regarding the crosstalk between coagulation and inflammation in the pathogenesis of vascular diseases [6]. In particular, our

*Address for Correspondence:. A. Phillip Owens III, PhD, University of North Carolina at Chapel Hill, 98 Manning Drive Campus Box 7035, Chapel Hill, North Carolina, 27599, Telephone: (919) 843 9543, Fax : (919) 966 7639, apowens3@email.unc.edu. 
laboratory is interested in the relationship between atherosclerosis and the procoagulant protein tissue factor (TF).

TF is the primary initiator of the extrinsic pathway of coagulation [7-8]. When it binds its ligand factor VIIa (FVIIa) a complex is formed that activates both FIX and FX resulting in the generation of thrombin and ultimately cross-linked fibrin [9]. TF is not normally exposed to flowing blood, but rather expressed by cells in the media, such as vascular smooth muscle cells (VSMCs), or cells in the adventitia, such as adventitial fibroblasts. It has been proposed to form a protective 'haemostatic envelope' to reduce blood loss in the event of vascular injury [10-11]. Importantly, TF expression is also induced in circulating monocytes, the major source of intravascular TF [12], during cardiovascular disease (CVD) and in the macrophages within atherosclerotic plaques [13]. It is speculated that TF is the main protein involved in triggering thrombosis after plaque rupture.

This review will discuss (1) the cellular sources of TF in atherosclerotic plaques, (2) the potential use of TF-positive microparticles (MPs) as a biomarker for CVD, and (3) currently used therapeutics to decrease the amount of TF in atherosclerotic plaques and in the circulation.

\section{TF Expression within Atherosclerotic Plaques}

The initiating event in atherosclerosis is still a mystery to both scientific and clinical researchers. However, after several decades of research, there are three prevailing hypotheses currently being tested: (1) the response-to-injury hypothesis [14-16], (2) the response-toretention hypothesis [17-18], and (3) the oxidative modification hypothesis [18-19]. These models are elegantly summarized by Stocker and Keaney [20]. Briefly, the response to injury hypothesis suggests the initiation of atherosclerosis begins with endothelial injury or dysfunction resulting in LDL deposition (resulting in progressive oxidative modification) into the subendothelial space leading to a constant 'autoimmune-like' attempt to continually heal this injury (critical event: endothelial injury/dysfunction). In contrast, the response-toretention hypothesis suggests LDL infiltrates specific sites within arteries due to transcytosis and arterial retention from proteoglycan binding results in lipoprotein aggregation and modification leading to triggering of the proinflammatory cascade (critical event: LDLmatrix interactions). Finally, the oxidative modification hypothesis results from trapped subendothelial LDL becoming oxidized (oxLDL) resulting in monocyte chemotaxis and foam cell formation (critical event: LDL oxidation). Regardless of the hypothesis, the end result is leukocyte adhesion, transmigration, foam cell formation, inflammation, VSMC migration, formation of a fatty streak, apoptosis, necrosis, release of proteases, and eventual weakening of the fibrous cap leading to atherothrombosis. Importantly, in all three of the hypotheses, TF expression is induced in atherosclerotic lesions with (1) the introduction of leukocytes in the subendothelial space $[5,21]$ and (2) modified LDL activation of receptor complexes on these leukocytes, VSMCs, and endothelial cells [22-28••].

High levels of TF are expressed in atherosclerotic plaques and is associated with both cellular (macrophages, VSMCs, and endothelial cells) and acellular (foam cell-derived debris within the necrotic core) regions [29-36]. Monocyte chemoattractant protein-1 
(MCP-1) is a potent chemokine involved in both the initiation and progression of atherosclerosis, and has been shown to induce TF expression in both monocyte/macrophages and VSMCs [37-38]. Aggregated LDL increases TF expression on human monocytes/ macrophages resulting in the release of biologically active TF-positive MPs [22]. Further, oxLDL is a potent activator of TF in monocytes, VSMCs, and endothelial cells resulting in the release of TF-positive MPs, which are highly procoagulant [23-28••, 39]. Indeed, atherosclerotic plaques have 200-fold higher concentrations of leukocyte, VSMC, and endothelial cell-derived MPs compared with circulating blood [40]. Importantly, more than $50 \%$ of the MPs isolated from the plaques were TF-positive [40]. Finally, increased TF expression is correlated with the progression of human atherosclerotic lesions, more than likely due to an increase in macrophage apoptosis and necrosis as the lesion expands [36].

The TF:FVIIa complex not only triggers clotting but also activates the protease-activated receptor 2 (PAR-2), which results in proinflammatory signaling [41-42•]. TF induction of proinflammatory cytokines and chemokines can result in further leukocyte recruitment to the atherosclerotic lesion, thus enhancing the progression of atherosclerosis $[6,9,13,34]$. VSMCs play a key role in atherosclerosis both in early and in late stages [43]. In early stages, VSMCs migrate from the media to the intima where they are trapped and proliferate to contribute to the development of fatty streaks. More advanced atherosclerotic lesions contain VSMCs that have a higher proliferative index and a greater synthetic capacity for extracellular matrix, particularly collagen, proteases and cytokines [44-46]. Similar to macrophages, late-stage VSMCs can express a variety of receptors for lipid uptake and can form foam-like cells, thereby participating in the accumulation of plaque lipid. Importantly, the presence of TF contributes to VSMC migration in vitro and in vivo [47], which appears to be due to the activation of the PAR-2 signaling pathway [48]. Further, TF:FVIIa activation of PAR-2 results in the secretion of the inflammatory cytokine IL- 6 and chemokine IL- 8 , which further the atherogenic immune phenotype [49]. In addition, ligation of the CD40 receptor, implicated in the atherogenic immune process, on VSMCs and monocyte/ macrophages can augment the expression of TF protein and activity in the atherosclerotic lesion [50-53]. These data suggest that TF may contribute to monocyte infiltration, macrophage foam cell formation, cyokine and chemokine production, and SMC migration to initiate and progress atherosclerosis.

Despite the plethora of in vitro studies supporting the idea that TF may contribute to the progression of atherosclerosis, it is important to note that the specific contribution of TF:FVIIa to atherosclerosis in mouse models remains uncertain. Our laboratory found that heterozygous $\mathrm{TF}$ mice $\left(\mathrm{TF}^{+/-}\right)$expressing only $50 \%$ of the normal level of $\mathrm{TF}$ had similar amounts of atherosclerosis compared to $\mathrm{TF}^{+/+}$mice on an atherogenic apolipoprotein $\mathrm{E}$ $\left(\right.$ Apoe $^{-/-}$) background [54]. Similarly, a deficiency of TF in bone marrow cells did not affect atherosclerosis in a low density lipoprotein receptor deficient $\left(\mathrm{Ldlr}^{-/}\right)$mouse model [54]. It should be noted that the Apoe $\mathrm{e}^{-/} / \mathrm{low}$ TF mice were not able to be studied due to premature death by 12 weeks of age and thus the contribution of non-hematopoietic TF could not be analyzed. Further, the Apoe ${ }^{-/-}$studies were conducted in 34 week old mice, which may have missed differences in the early stages of atherosclerosis. Additionally, Apoe ${ }^{-/-}$mice have defects in innate and adaptive immune response, independent of lipoproteins [55-56]. It is interesting that different results are observed with changes in levels of the natural inhibitor 
of TF called tissue factor pathway inhibitor (TFPI). For instance, a significant increase in atherosclerosis was observed in mice with a $50 \%$ reduction of TFPI $\left(\mathrm{Apoe}^{-/-/ \mathrm{Tfpi}^{+/}}\right)^{+/}$ compared to littermate controls [57]. Interestingly, a VSMC overexpressing TFPI mouse on an Apoe ${ }^{-/-}$background had less atherosclerosis [58••]. Finally, atherosclerotic studies utilizing PAR-2 deficient mice have not yet been conducted. Therefore, the role of TF:FVIIa and PAR-2 in atherogenesis needs further examination.

\section{Role of TF in Plaque Rupture and Atherothrombosis}

The most detrimental role of $\mathrm{TF}$ in atherosclerosis is the triggering of thrombosis after plaque rupture. Importantly, many studies have demonstrated TF in atherosclerotic plaques as the primary protein responsible for the thrombogenicity of the plaque and the primary cause of atherothrombosis [59-60]. While TF is associated with atherothrombosis, the extent of plaque thrombogenicity is dependent upon plaque composition. For example, TF present in plaques is associated with $60 \%$ of the cells in the atheroma, including: endothelial cells, VSMCs, and mostly monocyte/macrophages and foam cells [32-33, 36, 61-64]. Importantly, the level of TF in the plaque is strongly associated with plaque thrombogenicity [65]. In addition, Ardissino and colleagues demonstrated TF activity is higher in plaques from patients with unstable coronary syndromes and myocardial infarction versus patients with stable disease [66]. Further, the amount of TF protein in the plaque was correlated with TF activity [66]. However, some of the TF within the cellular milieu of the atheroma is associated with TFPI, and the presence of TFPI in human atherosclerotic plaques is associated with decreased TF activity [67-68, 69•, 70]. Importantly, a recent study demonstrated that lipoprotein (a) (Lp(a)), a complex of LDL and apolipoprotein a, can inactivate TFPI [71]. $\mathrm{Lp}(\mathrm{a})$ is a known risk factor for atherosclerosis, is upregulated in patients with unstable coronary syndromes, and accumulates in atherosclerotic plaques [72-73]. Therefore, the presence of $L p(a)$ may alter the TF/TFPI balance and increase the thrombogenicity of the plaque.

As mentioned previously, atherosclerotic plaques contain high levels of TF-positive MPs [40]. In addition, Mallat and colleagues demonstrated $97 \%$ of the total procoagulant activity extracted from atherosclerotic plaques was due to TF [74]. Subsequent proteomic analyses have demonstrated that over $90 \%$ of plaque-derived MPs are CD14 positive, suggesting monocyte/macrophage origin [75]. Bonderman and colleagues found increased TF activity associated with MPs taken from carotid atherosclerotic plaques [76]. Finally, Rautou and colleagues showed that plaque-derived MPs, but not circulating MPs, were able to activate endothelial cells resulting in leukocyte adhesion and transmigration [77••]. Together, these studies suggest that much of the $\mathrm{TF}$ that initiates atherothrombosis during plaque rupture is in the form of MPs.

It has been demonstrated that vessel wall TF is the primary cellular source that triggers thrombosis in animal models of arterial thrombosis [11, 78-79]. Importantly, carotid injury of atherosclerotic lesions in $\mathrm{Apoe}^{-/-} / \mathrm{Tfpi}^{+/-}$mice demonstrated a decreased time to occlusion versus littermate controls and this was attributed to increased TF activity [57]. In addition, hyperlipidemia is associated with a shorter occlusion time in mouse carotid arterial thrombosis models $[11,28 \bullet \bullet, 80 \bullet-81]$. The role of circulating TF-positive MPs in 
thrombosis can be evaluated using the laser-injury cremaster arteriole injury model. We recently, found that hematopoietic cell-derived, TF-positive MPs were increased during hyperlipidemic mice and enhanced thrombosis in this model [59]. Together, these studies indicate that TF and TF-positive MPs play a key role in thrombosis associated with atherosclerotic vessels.

\section{TF-positive MPs as a Biomarker of Atherothrombotic Disease and Thrombotic Risk}

MPs may serve as delivery vessels for certain proteins and nucleic acids (extensively reviewed in [82•]). However, many studies have demonstrated increases in certain MPs in a wide variety of disease states [83]. We believe that TF-positive MPs may serve as a potent biomarker of CVD and thrombotic risk.

Several studies have demonstrated an increase in expression of monocyte TF, monocytederived TF-positive MPs, and MP TF activity in the plasma of patients with

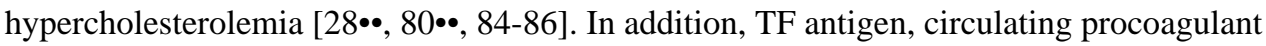
MPs, and TF-positive MPs are increased in patients with unstable angina, myocardial infarction, and patients undergoing angioplasty or coronary stenting [87-90]. Importantly, MP TF activity is increased in patients with acute myocardial infarction and atherosclerotic plaques [89, 91-92]. The role of TF-positive MPs in CVD and atherothrombosis has been extensively reviewed $[80 \bullet \bullet, 93 \bullet \cdot$. Together, these studies suggest that levels of TF-positive MPs, likely derived from activated monocytes, are increased in patients with CVD. However, unlike our recent finding that prospective analysis of MP TF activity can be predictive of venous thromboembolism (VTE) in patients with pancreatic cancer [94], further studies are needed to demonstrate the predictive value of MP TF activity in patients with CVD.

To address this question in an experimental model, we recently demonstrated that prolonged hypercholesterolemia, a known risk factor for atherosclerosis, results in a step-wise increase in the activation of coagulation, as measured by thrombin-antithrombin (TAT) and D-dimer, in both mice and monkeys [28••]. Moreover, we demonstrated that MP TF activity was also increased in a step-wise manner and was correlated with TAT, increased levels of oxLDL, and the inflammatory cytokine IL-6 [28••]. Importantly, levels of peripheral blood mononuclear cell (PBMC) TF were also increased with prolonged hypercholesterolemia. We further demonstrated that TF inhibition with an anti-TF antibody ablated the activation of coagulation and MP TF activity. Finally, we used bone marrow transplantation to demonstrate that TF-positive MPs were derived from hematopoietic cells. Together, we suggest that monocyte-derived TF is responsible for the systemic activation of coagulation and that MP TF activity serves as a potent biomarker of this response. While we did not examine atherosclerotic burden at each of the time-points, several studies have demonstrated progression of atherosclerosis in the $\mathrm{Ldlr}^{-/-}$model during the time-course utilized in our study [95-96]. This would suggest that circulating MP TF activity is likely to correlate with the level of atherosclerosis. 


\section{Potential Therapeutic Inhibition of TF and TF-induction of Thrombin and Fibrin in Atherothrombosis}

First line therapy for patients with advanced atherosclerosis and patients discharged post myocardial infarction usually includes administration of: (1) statins to lower LDL cholesterol and niacin or fibrate to raise HDL [97-98], (2) antiplatelet therapy consisting of aspirin or clopidogrel, (3) blockade of the renin angiotensin system via an angiotensin converting enzyme (ACE) inhibitor with or without an angiotensin II receptor blocker (ARB), and (4) administration of beta blockers [99]. However, statins also exhibit several pleiotrophic properties, such as anti-inflammatory responses and inhibition of prenylation of intracellular signaling proteins [100-101]. Importantly, statins have also been demonstrated to reduce TF expression and activity, both in vitro and in vivo, in several animal models of atherosclerosis and hypercholesterolemia as well as in humans [24, 26, 28••, 85-86, 100, 102-105] .

We recently demonstrated that oxLDL induction of TF in human monocytes is inhibited by pretreatment with simvastatin [28••]. In addition, simvastatin administration attenuated hypercholesterolemic increases in oxLDL, PBMC or white blood cell TF, MP TF activity, circulating MPs, and thrombin-antithrombin (independent of changes in LDL) in both mice and monkey study models [28••]. Similar LDL-independent effects of simvastatin and pravastatin resulted in reduced inflammation and thrombogenicity in hypercholesterolemic pigs and monkeys [106-107]. Regarding atherosclerosis, simvastatin and rosuvastatin administration reduced both aortic and atherosclerotic lesion TF in hypercholesterolemic mice without affecting LDL [100, 102]. Importantly, monocyte and macrophage expression of TF is inhibited by statins [24, 26, 85-86, 103-105]. This statin-induced reduction of TF is also demonstrated in vivo in type II familial hypercholesterolemic patients along with concomitant reductions in prothrombin fragmant F1 +2 [85-86]. These data suggest that simvastatin can decrease TF expression and activity, primarily in monocytic cells, and that this may be an alternative therapy for TF inhibition in atherosclerotic and atherothrombotic conditions.

It is interesting to note that almost $50 \%$ of patients who develop atherosclerosis and eventual atherothrombosis have levels of LDL cholesterol which are considered at or below the average range of an otherwise 'healthy' population $[17,108]$. Therefore, these patients could also benefit from the pleotrophic effects of statin therapy [100-101]. The key is to identify these 'normal' patients with advanced atherosclerotic disease using various other biomarkers, e.g. TF-positive MPs (as discussed in the previous section), and with screening of inflammatory markers. In a hallmark study, the justification for the use of statins in primary prevention (JUPITER) trial demonstrated preemptive administration of rosuvastatin to individuals with normal levels of LDL, but elevated levels of inflammation, could significantly reduce the incidence of major cardiovascular events [109]. Again, this demonstrates that inflammation may serve as a potent biomarker in patients with 'silent' atherosclerotic disease having normal lipid levels. In addition, a retrospective analysis of JUPITER found that VTE was also significantly reduced in this patient population [110••]. It 
was speculated that this reduction in events was due to statin-induced inhibition of TF expression $[110 \bullet \cdot$.

In addition to statins, another commonly used therapeutic also reduces both direct TF expression and activity in vitro and in vivo. Application of ACE inhibitors captopril, idrapril, and fosinopril, as well as the ARB losartan, dose-dependently decreased TF expression and activity in endotoxin-stimulated PBMCs [111]. Interestingly, ACE inhibition with enalapril also decreased levels of plasma TF antigen in patients with acute myocardial infarction [112]. Moreover, ACE inhibitors have been demonstrated to reduce the incidence of myocardial infarction, suggesting potential antithrombotic effects of this drug class [113-116]. This may occur, in part, independently of blood pressure inhibition by decreasing synthesis of IL- $1 \beta$ and TNF- $\alpha$ recruitment of monocytes to atherosclerotic plaques [111, 117-118]. Together, this data suggests ACE inhibitors and ARBs may have similar pleiotrophic effects to statins and that their antithrombotic outcomes may be, in part, due to reduced TF expression in monocytes.

\section{Conclusion}

In summary, high levels of TF are present in atherosclerotic plaques. Importantly, plaquederived TF is likely to be a major trigger of atherothrombosis and is the major determinant of the thrombogenicity of the atheroma. TF-positive MPs are generated in advanced atherosclerosis and may be a useful biomarker for monitoring atherosclerosis and thrombotic risk. Finally, there are several clinically used drugs that inhibit TF expression and this may add to the beneficial effects of these drugs.

\section{Acknowledgments}

This work was supported by a National Institutes of Health grants 1F32-HL099175-02 (APO III) and PO1HL006350-34 (NM).

\section{References and Recommended Reading}

Papers of particular interest, published recently, have been highlighted as:

- Of importance

-• Of major importance

1. Minino AM. Death in the United States, 2009. NCHS Data Brief. 2011; (64):1-8.

2. Roger VL, Go AS, Lloyd-Jones DM, et al. Heart disease and stroke statistics--2011 update: a report from the American Heart Association. Circulation. 2011; 123(4):e18-e209. [PubMed: 21160056]

3. Roger VL, Go AS, Lloyd-Jones DM, et al. Heart disease and stroke statistics--2012 update: a report from the American Heart Association. Circulation. 2012; 125(1):e2-e220. [PubMed: 22179539]

4. Heidenreich PA, Trogdon JG, Khavjou OA, et al. Forecasting the future of cardiovascular disease in the United States: a policy statement from the American Heart Association. Circulation. 2011; 123(8):933-944. [PubMed: 21262990]

5. Ross R. Atherosclerosis--an inflammatory disease. N Engl J Med. 1999; 340(2):115-126. [PubMed: 9887164]

6. Demetz G, Ott I. The Interface between Inflammation and Coagulation in Cardiovascular Disease. Int J Inflam. 2012; 2012:860301. [PubMed: 22518344] 
7. Bach RR. Initiation of coagulation by tissue factor. CRC Crit Rev Biochem. 1988; 23(4):339-368. [PubMed: 3067973]

8. Edgington TS, Mackman N, Brand K, Ruf W. The structural biology of expression and function of tissue factor. Thromb Haemost. 1991; 66(1):67-79. [PubMed: 1833852]

9. Mackman N. Role of tissue factor in hemostasis, thrombosis, and vascular development. Arterioscler Thromb Vasc Biol. 2004; 24(6):1015-1022. [PubMed: 15117736]

10. Pawlinski R, Pedersen B, Erlich J, Mackman N. Role of tissue factor in haemostasis, thrombosis, angiogenesis and inflammation: lessons from low tissue factor mice. Thromb Haemost. 2004; 92(3):444-450. [PubMed: 15351839]

11. Owens AP 3rd, Mackman N. Tissue factor and thrombosis: The clot starts here. Thromb Haemost. 2010; 104(3):432-439. [PubMed: 20539911]

12. Osterud B. Tissue factor expression in blood cells. Thromb Res. 2010; 125(Suppl 1):S31-34. [PubMed: 20149415]

13. Mackman N, Tilley RE, Key NS. Role of the extrinsic pathway of blood coagulation in hemostasis and thrombosis. Arterioscler Thromb Vasc Biol. 2007; 27(8):1687-1693. [PubMed: 17556654]

14. Ross R, Glomset JA. Atherosclerosis and the arterial smooth muscle cell: Proliferation of smooth muscle is a key event in the genesis of the lesions of atherosclerosis. Science. 1973; 180(4093): 1332-1339. [PubMed: 4350926]

15. Ross R, Glomset JA. The pathogenesis of atherosclerosis (second of two parts). N Engl J Med. 1976; 295(8):420-425. [PubMed: 778621]

16. Ross R, Glomset JA. The pathogenesis of atherosclerosis (first of two parts). N Engl J Med. 1976; 295(7):369-377. [PubMed: 819830]

17. Williams KJ, Tabas I. The response-to-retention hypothesis of early atherogenesis. Arterioscler Thromb Vasc Biol. 1995; 15(5):551-561. [PubMed: 7749869]

18. Capron L. [Pathogenesis of atherosclerosis: an update on the three main theories]. Ann Cardiol Angeiol (Paris). 1989; 38(10):631-634. [PubMed: 2698116]

19. Goldstein JL, Ho YK, Basu SK, Brown MS. Binding site on macrophages that mediates uptake and degradation of acetylated low density lipoprotein, producing massive cholesterol deposition. Proc Natl Acad Sci U S A. 1979; 76(1):333-337. [PubMed: 218198]

20. Stocker R, Keaney JF Jr. Role of oxidative modifications in atherosclerosis. Physiol Rev. 2004; 84(4):1381-1478. [PubMed: 15383655]

21. Breitenstein A, Tanner FC, Luscher TF. Tissue factor and cardiovascular disease: quo vadis? Circ J. 2010; 74(1):3-12. [PubMed: 19996531]

22. Liu ML, Reilly MP, Casasanto P, McKenzie SE, Williams KJ. Cholesterol enrichment of human monocyte/macrophages induces surface exposure of phosphatidylserine and the release of biologically-active tissue factor-positive microvesicles. Arterioscler Thromb Vasc Biol. 2007; 27(2):430-435. [PubMed: 17158353]

23. Bochkov VN, Mechtcheriakova D, Lucerna M, et al. Oxidized phospholipids stimulate tissue factor expression in human endothelial cells via activation of ERK/EGR-1 and $\mathrm{Ca}(++) / \mathrm{NFAT}$. Blood. 2002; 99(1):199-206. [PubMed: 11756172]

24. Schuff-Werner P, Claus G, Armstrong VW, Kostering H, Seidel D. Enhanced procoagulatory activity (PCA) of human monocytes/macrophages after in vitro stimulation with chemically modified LDL. Atherosclerosis. 1989; 78(2-3):109-112. [PubMed: 2783195]

25. Drake TA, Hannani K, Fei HH, Lavi S, Berliner JA. Minimally oxidized low-density lipoprotein induces tissue factor expression in cultured human endothelial cells. Am J Pathol. 1991; 138(3): 601-607. [PubMed: 2000938]

26. Meisel SR, Xu XP, Edgington TS, et al. Dose-Dependent Modulation of Tissue Factor Protein and Procoagulant Activity in Human Monocyte-Derived Macrophages by Oxidized Low Density Lipoprotein. J Atheroscler Thromb. 2011

27. Cui MZ, Penn MS, Chisolm GM. Native and oxidized low density lipoprotein induction of tissue factor gene expression in smooth muscle cells is mediated by both Egr-1 and Sp1. J Biol Chem. 1999; 274(46):32795-32802. [PubMed: 10551840]

28••. Owens AP 3rd, Passam FH, Antoniak S, et al. Monocyte tissue factor-dependent activation of coagulation in hypercholesterolemic mice and monkeys is inhibited by simvastatin. J Clin Invest. 
2012; 122(2):558-568. This paper demonstrates that simvastatin can reduce hypercholesterolemia induction of TF and the activation of coagulation, independent of lipidlowering. [PubMed: 22214850]

29. Borissoff JI, Heeneman S, Kilinc E, et al. Early atherosclerosis exhibits an enhanced procoagulant state. Circulation. 2010; 122(8):821-830. [PubMed: 20697022]

30. Annex BH, Denning SM, Channon KM, et al. Differential expression of tissue factor protein in directional atherectomy specimens from patients with stable and unstable coronary syndromes. Circulation. 1995; 91(3):619-622. [PubMed: 7828284]

31. Moreno PR, Bernardi VH, Lopez-Cuellar J, et al. Macrophages, smooth muscle cells, and tissue factor in unstable angina. Implications for cell-mediated thrombogenicity in acute coronary syndromes. Circulation. 1996; 94(12):3090-3097. [PubMed: 8989114]

32. Marmur JD, Thiruvikraman SV, Fyfe BS, et al. Identification of active tissue factor in human coronary atheroma. Circulation. 1996; 94(6):1226-1232. [PubMed: 8822973]

33. Wilcox JN, Smith KM, Schwartz SM, Gordon D. Localization of tissue factor in the normal vessel wall and in the atherosclerotic plaque. Proc Natl Acad Sci U S A. 1989; 86(8):2839-2843. [PubMed: 2704749]

34. Tremoli E, Camera M, Toschi V, Colli S. Tissue factor in atherosclerosis. Atherosclerosis. 1999; 144(2):273-283. [PubMed: 10407489]

35. Ardissino D, Merlini PA, Arlens R, et al. Tissue factor in human coronary atherosclerotic plaques. Clin Chim Acta. 2000; 291(2):235-240. [PubMed: 10675726]

36. Hatakeyama K, Asada Y, Marutsuka K, Sato Y, Kamikubo Y, Sumiyoshi A. Localization and activity of tissue factor in human aortic atherosclerotic lesions. Atherosclerosis. 1997; 133(2):213219. [PubMed: 9298681]

37. Schecter AD, Berman AB, Yi L, et al. MCP-1-dependent signaling in CCR2(-/-) aortic smooth muscle cells. J Leukoc Biol. 2004; 75(6):1079-1085. [PubMed: 15020650]

38. Schecter AD, Rollins BJ, Zhang YJ, et al. Tissue factor is induced by monocyte chemoattractant protein-1 in human aortic smooth muscle and THP-1 cells. J Biol Chem. 1997; 272(45):2856828573. [PubMed: 9353321]

39. Schecter AD, Spirn B, Rossikhina M, et al. Release of active tissue factor by human arterial smooth muscle cells. Circ Res. 2000; 87(2):126-132. [PubMed: 10903996]

40. Leroyer AS, Isobe H, Leseche G, et al. Cellular origins and thrombogenic activity of microparticles isolated from human atherosclerotic plaques. J Am Coll Cardiol. 2007; 49(7):772-777. [PubMed: 17306706]

41. Antoniak S, Pawlinski R, Mackman N. Protease-activated receptors and myocardial infarction. IUBMB Life. 2011; 63(6):383-389. [PubMed: 21438116]

42. Borissoff JI, Spronk HM, ten Cate H. The hemostatic system as a modulator of atherosclerosis. N Engl J Med. 2011; 364(18):1746-1760. This review summarizes the current knowledge of coagulation factors examined in atherosclerosis. [PubMed: 21542745]

43. Doran AC, Meller N, McNamara CA. Role of smooth muscle cells in the initiation and early progression of atherosclerosis. Arterioscler Thromb Vasc Biol. 2008; 28(5):812-819. [PubMed: 18276911]

44. Owens GK, Kumar MS, Wamhoff BR. Molecular regulation of vascular smooth muscle cell differentiation in development and disease. Physiol Rev. 2004; 84(3):767-801. [PubMed: 15269336]

45. Campbell JH, Campbell GR. The role of smooth muscle cells in atherosclerosis. Curr Opin Lipidol. 1994; 5(5):323-330. [PubMed: 7858906]

46. Worth NF, Rolfe BE, Song J, Campbell GR. Vascular smooth muscle cell phenotypic modulation in culture is associated with reorganisation of contractile and cytoskeletal proteins. Cell Motil Cytoskeleton. 2001; 49(3):130-145. [PubMed: 11668582]

47. Pyo RT, Sato Y, Mackman N, Taubman MB. Mice deficient in tissue factor demonstrate attenuated intimal hyperplasia in response to vascular injury and decreased smooth muscle cell migration. Thromb Haemost. 2004; 92(3):451-458. [PubMed: 15351840] 
48. Marutsuka K, Hatakeyama K, Sato Y, Yamashita A, Sumiyoshi A, Asada Y. Protease-activated receptor 2 (PAR2) mediates vascular smooth muscle cell migration induced by tissue factor/factor VIIa complex. Thromb Res. 2002; 107(5):271-276. [PubMed: 12479889]

49. Demetz G, Seitz I, Stein A, et al. Tissue Factor-Factor VIIa complex induces cytokine expression in coronary artery smooth muscle cells. Atherosclerosis. 2010; 212(2):466-471. [PubMed: 20708733]

50. Schonbeck U, Mach F, Sukhova GK, et al. CD40 ligation induces tissue factor expression in human vascular smooth muscle cells. Am J Pathol. 2000; 156(1):7-14. [PubMed: 10623647]

51. Mach F, Schonbeck U, Bonnefoy JY, Pober JS, Libby P. Activation of monocyte/macrophage functions related to acute atheroma complication by ligation of CD40: induction of collagenase, stromelysin, and tissue factor. Circulation. 1997; 96(2):396-399. [PubMed: 9244201]

52. Mach F, Schonbeck U, Sukhova GK, et al. Functional CD40 ligand is expressed on human vascular endothelial cells, smooth muscle cells, and macrophages: implications for CD40-CD40 ligand signaling in atherosclerosis. Proc Natl Acad Sci U S A. 1997; 94(5):1931-1936. [PubMed: 9050882]

53. Schonbeck U, Sukhova GK, Shimizu K, Mach F, Libby P. Inhibition of CD40 signaling limits evolution of established atherosclerosis in mice. Proc Natl Acad Sci U S A. 2000; 97(13):74587463. [PubMed: 10861012]

54. Tilley RE, Pedersen B, Pawlinski R, et al. Atherosclerosis in mice is not affected by a reduction in tissue factor expression. Arterioscler Thromb Vasc Biol. 2006; 26(3):555-562. [PubMed: 16385085]

55. Roselaar SE, Daugherty A. Apolipoprotein E-deficient mice have impaired innate immune responses to Listeria monocytogenes in vivo. J Lipid Res. 1998; 39(9):1740-1743. [PubMed: 9741685]

56. Pepe MG, Curtiss LK. Apolipoprotein E is a biologically active constituent of the normal immunoregulatory lipoprotein, LDL-In. J Immunol. 1986; 136(10):3716-3723. [PubMed: 3701060]

57. Westrick RJ, Bodary PF, Xu Z, Shen YC, Broze GJ, Eitzman DT. Deficiency of tissue factor pathway inhibitor promotes atherosclerosis and thrombosis in mice. Circulation. 2001; 103(25): 3044-3046. [PubMed: 11425765]

58••. Pan S, White TA, Witt TA, Chiriac A, Mueske CS, Simari RD. Vascular-directed tissue factor pathway inhibitor overexpression regulates plasma cholesterol and reduces atherosclerotic plaque development. Circ Res. 2009; 105(7):713-720. 718 p following 720. This paper demonstrates TFPI overexpression can reduce experimental atherosclerosis, which implicates TF in the atherosclerotic process. [PubMed: 19713537]

59. Owens AP 3rd, Mackman N. Sources of tissue factor that contribute to thrombosis after rupture of an atherosclerotic plaque. Thromb Res. 2012; 129(Suppl 2):S30-33.

60. Fuster V, Fallon JT, Badimon JJ, Nemerson Y. The unstable atherosclerotic plaque: clinical significance and therapeutic intervention. Thromb Haemost. 1997; 78(1):247-255. [PubMed: 9198161]

61. Thiruvikraman SV, Guha A, Roboz J, Taubman MB, Nemerson Y, Fallon JT. In situ localization of tissue factor in human atherosclerotic plaques by binding of digoxigenin-labeled factors VIIa and X. Lab Invest. 1996; 75(4):451-461. [PubMed: 8874378]

62. Ichikawa K, Nakagawa K, Hirano K, Sueishi K. The localization of tissue factor and apolipoprotein(a) in atherosclerotic lesions of the human aorta and their relation to fibrinogenfibrin transition. Pathol Res Pract. 1996; 192(3):224-232. [PubMed: 8739469]

63. Muhlfelder TW, Teodorescu V, Rand J, Rosman A, Niemetz J. Human atheromatous plaque extracts induce tissue factor activity (TFa) in monocytes and also express constitutive TFa. Thromb Haemost. 1999; 81(1):146-150. [PubMed: 10348707]

64. Jonasson L, Holm J, Skalli O, Bondjers G, Hansson GK. Regional accumulations of T cells, macrophages, and smooth muscle cells in the human atherosclerotic plaque. Arteriosclerosis. 1986; 6(2):131-138. [PubMed: 2937395]

65. Toschi V, Gallo R, Lettino M, et al. Tissue factor modulates the thrombogenicity of human atherosclerotic plaques. Circulation. 1997; 95(3):594-599. [PubMed: 9024145] 
66. Ardissino D, Merlini PA, Ariens R, Coppola R, Bramucci E, Mannucci PM. Tissue-factor antigen and activity in human coronary atherosclerotic plaques. Lancet. 1997; 349(9054):769-771. [PubMed: 9074577]

67. Kaikita K, Takeya M, Ogawa H, Suefuji H, Yasue H, Takahashi K. Co-localization of tissue factor and tissue factor pathway inhibitor in coronary atherosclerosis. J Pathol. 1999; 188(2):180-188. [PubMed: 10398162]

68. Caplice NM, Mueske CS, Kleppe LS, Simari RD. Presence of tissue factor pathway inhibitor in human atherosclerotic plaques is associated with reduced tissue factor activity. Circulation. 1998; 98(11):1051-1057. [PubMed: 9736590]

69•. Basavaraj MG, Sovershaev MA, Egorina EM, et al. Circulating monocytes mirror the imbalance in TF and TFPI expression in carotid atherosclerotic plaques with lipid-rich and calcified morphology. Thromb Res. 2012; 129(4):e134-141. This paper highlights the importance of the TF/TFPI ratio in circulating monocytes in determining thrombogenicity of atherosclerotic disease. [PubMed: 22178066]

70. Morishita E, Asakura H, Saito M, et al. Elevated plasma levels of free-form of TFPI antigen in hypercholesterolemic patients. Atherosclerosis. 2001; 154(1):203-212. [PubMed: 11137101]

71. Caplice NM, Panetta C, Peterson TE, et al. Lipoprotein (a) binds and inactivates tissue factor pathway inhibitor: a novel link between lipoproteins and thrombosis. Blood. 2001; 98(10):2980 2987. [PubMed: 11698280]

72. Kronenberg F, Kronenberg MF, Kiechl S, et al. Role of lipoprotein(a) and apolipoprotein(a) phenotype in atherogenesis: prospective results from the Bruneck study. Circulation. 1999; 100(11):1154-1160. [PubMed: 10484534]

73. Rath M, Pauling L. Immunological evidence for the accumulation of lipoprotein(a) in the atherosclerotic lesion of the hypoascorbemic guinea pig. Proc Natl Acad Sci U S A. 1990; 87(23): 9388-9390. [PubMed: 2147514]

74. Mallat Z, Hugel B, Ohan J, Leseche G, Freyssinet JM, Tedgui A. Shed membrane microparticles with procoagulant potential in human atherosclerotic plaques: a role for apoptosis in plaque thrombogenicity. Circulation. 1999; 99(3):348-353. [PubMed: 9918520]

75. Mayr M, Grainger D, Mayr U, et al. Proteomics, metabolomics, and immunomics on microparticles derived from human atherosclerotic plaques. Circ Cardiovasc Genet. 2009; 2(4): 379-388. [PubMed: 20031610]

76. Bonderman D, Teml A, Jakowitsch J, et al. Coronary no-reflow is caused by shedding of active tissue factor from dissected atherosclerotic plaque. Blood. 2002; 99(8):2794-2800. [PubMed: 11929768]

77••. Rautou PE, Leroyer AS, Ramkhelawon B, et al. Microparticles from human atherosclerotic plaques promote endothelial ICAM-1-dependent monocyte adhesion and transendothelial migration. Circ Res. 2011; 108(3):335-343. This paper describes how plaque-derived MPs can contribute to monocyte transmigration into the atheroma resulting in continued progression of atherosclerosis. [PubMed: 21164106]

78. Wang L, Miller C, Swarthout RF, Rao M, Mackman N, Taubman MB. Vascular smooth musclederived tissue factor is critical for arterial thrombosis after ferric chloride-induced injury. Blood. 2009; 113(3):705-713. [PubMed: 18931346]

79. Kretz CA, Vaezzadeh N, Gross PL. Tissue factor and thrombosis models. Arterioscler Thromb Vasc Biol. 2010; 30(5):900-908. [PubMed: 20393156]

80••. Owens AP 3rd, Mackman N. Microparticles in hemostasis and thrombosis. Circ Res. 2011; 108(10):1284-1297. This review summarizes the current knowledge on MPs in hemostasis and thrombosis, including the role of TF-positive MPs in cardiovascular disease. [PubMed: 21566224]

81. Eitzman DT, Westrick RJ, Xu Z, Tyson J, Ginsburg D. Hyperlipidemia promotes thrombosis after injury to atherosclerotic vessels in apolipoprotein E-deficient mice. Arterioscler Thromb Vasc Biol. 2000; 20(7):1831-1834. [PubMed: 10894825]

82•. Mause SF, Weber C. Microparticles: protagonists of a novel communication network for intercellular information exchange. Circ Res. 2010; 107(9):1047-1057. This review summarizes 
how MPs can act as messanger vessicles to deliver various proteins to adjacent or distant cells. [PubMed: 21030722]

83. Amabile N, Rautou PE, Tedgui A, Boulanger CM. Microparticles: key protagonists in cardiovascular disorders. Semin Thromb Hemost. 2010; 36(8):907-916. [PubMed: 21069633]

84. Matsumoto N, Nomura S, Kamihata H, Kimura Y, Iwasaka T. Increased level of oxidized LDLdependent monocyte-derived microparticles in acute coronary syndrome. Thromb Haemost. 2004; 91(1):146-154. [PubMed: 14691580]

85. Ferro D, Basili S, Alessandri C, Cara D, Violi F. Inhibition of tissue-factor-mediated thrombin generation by simvastatin. Atherosclerosis. 2000; 149(1):111-116. [PubMed: 10704621]

86. Ferro D, Basili S, Alessandri C, Mantovani B, Cordova C, Violi F. Simvastatin reduces monocytetissue-factor expression type IIa hypercholesterolaemia. Lancet. 1997; 350(9086):1222. [PubMed: 9652566]

87. Soejima H, Ogawa $\mathrm{H}$, Yasue $\mathrm{H}$, et al. Heightened tissue factor associated with tissue factor pathway inhibitor and prognosis in patients with unstable angina. Circulation. 1999; 99(22):29082913. [PubMed: 10359735]

88. Mallat Z, Benamer H, Hugel B, et al. Elevated levels of shed membrane microparticles with procoagulant potential in the peripheral circulating blood of patients with acute coronary syndromes. Circulation. 2000; 101(8):841-843. [PubMed: 10694520]

89. Morel O, Pereira B, Averous G, et al. Increased levels of procoagulant tissue factor-bearing microparticles within the occluded coronary artery of patients with ST-segment elevation myocardial infarction: role of endothelial damage and leukocyte activation. Atherosclerosis. 2009; 204(2):636-641. [PubMed: 19091315]

90. Steppich B, Mattisek C, Sobczyk D, Kastrati A, Schomig A, Ott I. Tissue factor pathway inhibitor on circulating microparticles in acute myocardial infarction. Thromb Haemost. 2005; 93(1):35-39. [PubMed: 15630488]

91. Huisse MG, Lanoy E, Tcheche D, et al. Prothrombotic markers and early spontaneous recanalization in ST-segment elevation myocardial infarction. Thromb Haemost. 2007; 98(2):420 426. [PubMed: 17721626]

92. Huisse MG, Ajzenberg N, Feldman L, Guillin MC, Steg PG. Microparticle-linked tissue factor activity and increased thrombin activity play a potential role in fibrinolysis failure in ST-segment elevation myocardial infarction. Thromb Haemost. 2009; 101(4):734-740. [PubMed: 19350119]

93••. Rautou PE, Vion AC, Amabile N, et al. Microparticles, vascular function, and atherothrombosis. Circ Res. 2011; 109(5):593-606. This review summarizes how MPs may contribute to the process of atherothrombosis. [PubMed: 21852557]

94. Khorana AA, Francis CW, Menzies KE, et al. Plasma tissue factor may be predictive of venous thromboembolism in pancreatic cancer. J Thromb Haemost. 2008; 6(11):1983-1985. [PubMed: 18795992]

95. Ma Y, Wang W, Zhang J, et al. Hyperlipidemia and atherosclerotic lesion development in ldlrdeficient mice on a long-term high-fat diet. PLoS One. 2012; 7(4):e35835. [PubMed: 22558236]

96. Kowala MC, Recce R, Beyer S, Gu C, Valentine M. Characterization of atherosclerosis in LDL receptor knockout mice: macrophage accumulation correlates with rapid and sustained expression of aortic MCP-1/JE. Atherosclerosis. 2000; 149(2):323-330. [PubMed: 10729382]

97. Steinberg D. The pathogenesis of atherosclerosis. An interpretive history of the cholesterol controversy, part IV: the 1984 coronary primary prevention trial ends it--almost. J Lipid Res. 2006; 47(1):1-14. [PubMed: 16227628]

98. Nissen SE, Nicholls SJ, Sipahi I, et al. Effect of very high-intensity statin therapy on regression of coronary atherosclerosis: the ASTEROID trial. JAMA. 2006; 295(13):1556-1565. [PubMed: 16533939]

99. Antman EM, Anbe DT, Armstrong PW, et al. ACC/AHA guidelines for the management of patients with ST-elevation myocardial infarction--executive summary: a report of the American College of Cardiology/American Heart Association Task Force on Practice Guidelines (Writing Committee to Revise the 1999 Guidelines for the Management of Patients With Acute Myocardial Infarction). Circulation. 2004; 110(5):588-636. [PubMed: 15289388] 
100. Monetti M, Canavesi M, Camera M, et al. Rosuvastatin displays anti-atherothrombotic and antiinflammatory properties in apoE-deficient mice. Pharmacol Res. 2007; 55(5):441-449. [PubMed: 17350858]

101. Tuomisto TT, Lumivuori H, Kansanen E, et al. Simvastatin has an anti-inflammatory effect on macrophages via upregulation of an atheroprotective transcription factor, Kruppel-like factor 2. Cardiovasc Res. 2008; 78(1):175-184. [PubMed: 18192240]

102. Bea F, Blessing E, Shelley MI, Shultz JM, Rosenfeld ME. Simvastatin inhibits expression of tissue factor in advanced atherosclerotic lesions of apolipoprotein E deficient mice independently of lipid lowering: potential role of simvastatin-mediated inhibition of Egr-1 expression and activation. Atherosclerosis. 2003; 167(2):187-194. [PubMed: 12818400]

103. Aikawa M, Rabkin E, Sugiyama S, et al. An HMG-CoA reductase inhibitor, cerivastatin, suppresses growth of macrophages expressing matrix metalloproteinases and tissue factor in vivo and in vitro. Circulation. 2001; 103(2):276-283. [PubMed: 11208689]

104. Baetta R, Camera M, Comparato C, Altana C, Ezekowitz MD, Tremoli E. Fluvastatin reduces tissue factor expression and macrophage accumulation in carotid lesions of cholesterol-fed rabbits in the absence of lipid lowering. Arterioscler Thromb Vasc Biol. 2002; 22(4):692-698. [PubMed: 11950712]

105. Colli S, Eligini S, Lalli M, Camera M, Paoletti R, Tremoli E. Vastatins inhibit tissue factor in cultured human macrophages. A novel mechanism of protection against atherothrombosis. Arterioscler Thromb Vasc Biol. 1997; 17(2):265-272. [PubMed: 9081680]

106. Sukhova GK, Williams JK, Libby P. Statins reduce inflammation in atheroma of nonhuman primates independent of effects on serum cholesterol. Arterioscler Thromb Vasc Biol. 2002; 22(9):1452-1458. [PubMed: 12231565]

107. Casani L, Sanchez-Gomez S, Vilahur G, Badimon L. Pravastatin reduces thrombogenicity by mechanisms beyond plasma cholesterol lowering. Thromb Haemost. 2005; 94(5):1035-1041. [PubMed: 16363247]

108. Brown MS, Goldstein JL. A receptor-mediated pathway for cholesterol homeostasis. Science. 1986; 232(4746):34-47. [PubMed: 3513311]

109. Ridker PM, Fonseca FA, Genest J, et al. Baseline characteristics of participants in the JUPITER trial, a randomized placebo-controlled primary prevention trial of statin therapy among individuals with low low-density lipoprotein cholesterol and elevated high-sensitivity C-reactive protein. Am J Cardiol. 2007; 100(11):1659-1664. [PubMed: 18036365]

110••. Glynn RJ, Danielson E, Fonseca FA, et al. A randomized trial of rosuvastatin in the prevention of venous thromboembolism. N Engl J Med. 2009; 360(18):1851-1861. This paper provides the first description of how statin therapy can prevent thrombotic events in relatively healthy patients with no history of hypercholesterolemia. [PubMed: 19329822]

111. Napoleone E, Di Santo A, Camera M, Tremoli E, Lorenzet R. Angiotensin-converting enzyme inhibitors downregulate tissue factor synthesis in monocytes. Circ Res. 2000; 86(2):139-143. [PubMed: 10666408]

112. Soejima $H$, Ogawa $H$, Yasue $H$, et al. Angiotensin-converting enzyme inhibition reduces monocyte chemoattractant protein-1 and tissue factor levels in patients with myocardial infarction. J Am Coll Cardiol. 1999; 34(4):983-988. [PubMed: 10520779]

113. Yusuf S, Pepine CJ, Garces C, et al. Effect of enalapril on myocardial infarction and unstable angina in patients with low ejection fractions. Lancet. 1992; 340(8829):1173-1178. [PubMed: 1359258]

114. GISSI-3: effects of lisinopril and transdermal glyceryl trinitrate singly and together on 6-week mortality and ventricular function after acute myocardial infarction. Lancet. 1994; 343(8906): 1115-1122. [PubMed: 7910229]

115. The SOLVD Investigators. Effect of enalapril on survival in patients with reduced left ventricular ejection fractions and congestive heart failure. N Engl J Med. 1991; 325(5):293-302. [PubMed: 2057034]

116. The SOLVD Investigattors. Effect of enalapril on mortality and the development of heart failure in asymptomatic patients with reduced left ventricular ejection fractions. N Engl J Med. 1992; 327(10):685-691. [PubMed: 1463530] 
117. Schindler R, Dinarello CA, Koch KM. Angiotensin-converting-enzyme inhibitors suppress synthesis of tumour necrosis factor and interleukin 1 by human peripheral blood mononuclear cells. Cytokine. 1995; 7(6):526-533. [PubMed: 8580368]

118. Fukuzawa M, Satoh J, Sagara M, et al. Angiotensin converting enzyme inhibitors suppress production of tumor necrosis factor-alpha in vitro and in vivo. Immunopharmacology. 1997; 36(1):49-55. [PubMed: 9129996] 